\title{
Prevalence of Fruit and Vegetable Consumption in HIV-Positive Patients in Antiretroviral treatment (Tarv) at Nampula Central Hospital
}

\author{
Sousa Gastao* \\ Master's in Food Safety, University of Lisbon, Portugal \\ *Corresponding Author: Sousa Gastao, Master's in Food Safety, University of Lisbon, Portugal
}

Received: November 07, 2019; Published: November 13, 2019

DOI: $10.31080 /$ ASNH.2019.03.0548

\begin{abstract}
The quality of life of a positive HIV patient is dependent on a stable immune system and influenced by a balanced diet, adapted to their specific needs. The present study aimed to evaluate the frequency of fruit and vegetable consumption in HIV-positive patients who had been treating anti-retroviral for at least one month at nampula Central Hospital. This descriptive cross-sectional study involved eighty individuals of both sexes aged between 18 and 59 years and data collection was performed using QFA. The results of this study indicate a low frequency of fruit and vegetable consumption, since they had a frequency of consumption less than once a day in the case of fruits of $42.5 \%$ (18.7\% men and $23.8 \%$ women), and in the case of vegetables of $23.7 \%(12.5 \%$ men and $11.2 \%$ women). These results point to the need to make interventions in order to promote the consumption of fruits and vegetables in patients in Tarv.
\end{abstract}

Keywords: Eating Habits; Frequency of Consumption; Antiretroviral Treatment.

\section{Abbreviation}

WHO: World Health Organization; QFA: Food Frequency Questionnaire; SETSAN: Technical Secretariat for Food and Nutrition Safety; AIDS: Acquired Immunodeficiency Syndrome; Tarv: Antiretroviral Treatment; HIV: Human Immunodeficiency Virus.

\section{Introduction}

Acquired Immunodeficiency Syndrome (AIDS) is an infection caused by the human immunodeficiency virus (HIV), which affects the function and number of CD4+ T lymphocytes with immunological alteration [1,2] as acharacteristic. HIV destroys CD4+ cells and the immune system becomes weaker and weaker as cd4+cell level decreases, disabling the immune system from fighting infections also called opportunistic infections (IOs) such as tuberculosis, pneumonia, herpes and meningitis [1,2].

AIDS is a global problem, estimates indicate that around 33.4 million people worldwide are infected, and sub-Saharan Africa remains the region most affected by HIV, with $67 \%$ of all individuals living with HIV and 75\% of AIDS deaths occurred in 2007 $[3,4]$. In Mozambique in the population universe of approximately 20,366,795 of approximately 1.6 million people live with HIV and AIDS of which, $55.5 \%$ are women, $9.2 \%$ are children under 15 years of age and the prevalence rate in men is $11.5 \%$ in the age group of 15 to 49 years of age [4].

Advances in anti-retroviral therapy (Tarv) have allowed the suppression of viral replication, improved quality of life and longevity of people living with HIV and AIDS, revealing reduced morbidity and mortality rates associated with infection [2]. Due to several factors all individuals with HIV infection have a high risk of becoming malnourished, which is worrying because it is known that nutritional deficiencies are associated with the accelerated progression of HIV infection [1]. 
HIV patients need a diet that provides them with all the nutrients essential to meet their increased nutritional needs and thus contribute to either the prevention of weight loss or maintenance of the infection as well as for the development or maintenance of muscle mass [5]. Several factors such as viral infection load, type and Intolerance to Tarv, drug/nutrient interactions have influenced nutritional needsd os hiv positive patients [2]. From this perspective, there is a need to know the previous nutritional status of patients in order to be able to provide nutritional support in order to improve the general health status, stabilize their nutritional status before and during treatment, and support the recovery of opportunistic infections [1,5].

WHO defines as minimum consumption of fruits and vegetables 400 grams/day the equivalent of five daily portions, and there is evidence that their consumption decreases the risk of chronic diseases as well as helps hiv-positive patients reduce micro deficiency nutrients especially those with antioxidant characteristics (vitamins C, A, E and selenium) that intervene in the regulation of metabolism, thus favoring immunological responses $[6,7]$.

Studies show that antioxidants help the immune system slow the evolution of HIV infection $[7,8]$. These vitamins and minerals can be found in fruits and vegetables [7-9]. Despite this evidence, fruit and vegetable consumption is still insufficient, both in developed and developing countries as is the case in Mozambique [8].

A study on nutritional status and food profile in 37 HIV patients observed that $66 \%$ of patients consumed fruits and vegetables below WHO recommendations [10]. In another study conducted in the Port on food consumption, it was found that $52.3 \%$ of the study participants had inadequate consumption of fruits and vegetables [11]. Nutritional deficiencies are associated with the accelerated progression of HIV infection, and it is of great importance to study the frequency of fruit and vegetable consumption in these, as they help slow the evolution of the disease. This work was carried out because there are no studies published in Mozambique evaluating the frequency of fruit and vegetable consumption in hiv-positive patients who are in Tarv.

\section{Objectives}

General

- $\quad$ Assess the frequency of fruit and vegetable consumption in HIV-positive patients in Tarv at nampula Central Hospital.
Specific

1. Classify the frequency of fruit and vegetable consumption in HIV-positive patients in Tarv according to WHO recommendations;

2. Estimate the frequency of fruit and vegetable consumption in HIV-positive patients in Tarv through an adapted QFA;

3. Evaluate the frequency of fruit and vegetable consumption according to gender and in outpatient and outpatient patients.

\section{Methodology}

General description of the study

This is a descriptive cross-sectional study involving HIV-positive patients in Anti-Retroviral Treatment (Tarv) at nampula Central Hospital.

\section{Sample selection}

The sample for the study consisted of 80 individuals of Mozambican nationality, of both sexes with a minimum age of 18 years and maximum of 59 years, who had been taking anti-retroviral treatment for at least one month at nampula Central Hospital. The sampling technique was for convenience since hiv cases that arose in the consultation of medicine for hiv-positive outpatient clinics and in patients admitted to the Medical I ward. were presented on biochemical examination of CD4+ $<350$ cells per ml of blood and performing antiretroviral treatment with Zidovudine (AZT) medication, and Efavirenz.

\section{Data collection}

Data collection was performed through a food frequency questionnaire (FFQ) previously validated by the Hygiene and Epidemiology Service of the Faculty of Medicine of the University of Porto. In the context of this study, the items related to the group of fruits and vegetables were used from the original questionnaire, adapting them to the reality of the country. The selection of this type of questionnaire as an information collection method was mainly due to the nature of the study, which aimed to assess frequency of consumption of fruits and vegetables.

The questionnaire consisted of a list of foods (fruits and vegetables), with ten categories of frequency of consumption (never, $<1$ time per month, 1-3 times a month, once a week, 2-4 times a week, 5-6 times a week, once a day, 2-3 times a day, 4-5 times a day and 6+ times a day), the average amount category in grams (smaller, equal 
and greater) and the last category that includes theconsumption (seasonality). Inadequate consumption of fruits and vegetables was considered the frequency equal to or less than once a day.

To facilitate the understanding of the questions and to obtain a more approximate estimate of the amount consumed, the individual was informed about the concept of "portion", given some examples of fruit and vegetable portions, based on the manual of food quantifications prepared by the Faculty of Sciences of Health of the Lurio University, with the aim of illustrating the quantities of food.

\section{Statistical analysis}

For the preparation of the database and statistical analysis, the statistical program SPSS version 14.0 for Windows was used. The variables were analyzed and represented by the relevant descriptive statistics: absolute frequency (n) and relative (\%). In the comparison between the frequency of consumption of fruits and vegetables by sexes, the Chi-square significance test was applied to test the association between variables, and the significance level was adopted at $5 \%(\mathrm{P}<0.05)$.

\section{Ethical aspects}

The methodology proposed in the study was in accordance with the ethical principles under investigation, and the rights of participants are always safeguarded according to the Helsinki Declaration. The participant recognized their rights in relation to the refusal to participate in the study, privacy and information. The anonymity of the participants was guaranteed by assigning an identification number of the questionnaire, which were only crossed with their data through a database in digital format.

\section{Results}

In this study, 80 individuals were interviewed, 44 females (55\%), the mean age was 34 years and it was observed that more HIV positive patients emerged from the outpatient consultation $82.5 \%$ (Table 1). Statistically significant differences were observed in the evaluation of the frequency of fruit and vegetable consumption for all analyses $(\mathrm{p}<0.05)$.

In the evaluation of the minimum consumption frequency (1 time per day), it was found that $23.8 \%$ of women and $18.7 \%$ men reported consuming fruits, and for vegetables it was observed that $12.5 \%$ of men and $11.2 \%$ women said they had minimum daily consumption (Table 2). In these patients, it was observed that the majority of the interviewees had a lower consumption than once a day $42.5 \%$ in the case of fruits and $23.7 \%$ in the case of vegetables. Regarding the frequency of consumption equal to two/three or five times a day it was observed that $18.8 \%$ of men and $21.2 \%$ women had this frequency of fruit consumption, and for vegetables $25 \%$ of women and $27.5 \%$ men. Fruit and vegetable consumption greater than two/three times a day was considered as an adequate frequency of consumption.

\begin{tabular}{|l|l|l|l|}
\hline Variables & $\mathbf{N}$ & $\mathbf{\%}$ & $\mathbf{P}$ \\
\hline Sex & & & \\
Male & 36 & $45 \%$ & 0,06 \\
Female & 44 & $55 \%$ & \\
Age & & & \\
18-35 years old & 32 & $40 \%$ & 0,04 \\
$36-48$ years old & 30 & $37,5 \%$ & \\
$49-59$ years old & 18 & $22,5 \%$ & \\
Inquiry & & & \\
Outpatient & 66 & $82,5 \%$ & 0,03 \\
Boarding school & 14 & $17,5 \%$ & \\
\hline
\end{tabular}

Table 1: Characterization of patients.

\begin{tabular}{|l|c|c|c|c|}
\hline Frequency & $\begin{array}{c}\text { All (no. 80) } \\
\text { N (\%) }\end{array}$ & $\begin{array}{c}\text { Male } \\
\text { N (\%) }\end{array}$ & $\begin{array}{c}\text { Female P } \\
\mathbf{N}(\%)\end{array}$ & $\mathbf{P}$ \\
\hline Fruits & $3(3,8)$ & $2(2,5)$ & $1(1,3)$ & 0,04 \\
\hline Never & $34(42,5)$ & $15(18,7)$ & $19(23,8)$ & \\
\hline 2-3 Times a day & $17(21,3)$ & $7(8,8)$ & $10(12,5)$ & \\
\hline 4-5 Times a day & $15(18,7)$ & $8(10)$ & $7(8,7)$ & \\
\hline 6+ Times a day & $11(13,7)$ & $4(5)$ & $7(8,7)$ & \\
\hline Total & $80(100)$ & $36(45)$ & $44(55)$ & \\
\hline Vegetables & $5(6,3)$ & $0(0)$ & $5(6,3)$ & 0,04 \\
Never & & & & \\
\hline 1 Times a day & $19(23,7)$ & $10(12,5)$ & $9(11,2)$ & \\
\hline 2-3 Times a day & $28(35)$ & $16(20)$ & $12(15)$ & \\
\hline 4-5 Times a day & $14(17,50$ & $6(7,5)$ & $8(10)$ & \\
\hline 6+ Times a day & $14(17,50$ & $4(5)$ & $10912,5)$ & \\
\hline Total & $80(100)$ & $36(45)$ & $44(55)$ & \\
\hline
\end{tabular}

Table 2: Daily frequency of consumption of fruits and vegetables. 
In the evaluation of the weekly frequency of fruit and vegetable consumption, it was observed that $15 \%$ of men and $17.6 \%$ of women consumed fruits and vegetables equal to or greater than four times a week, while $30.1 \%$ of men and $37.6 \%$ reported having a frequency equal to or less than three times a week the consumption of fruits and vegetables (Table 3). Regarding the frequency of monthly consumption, it was found that $57.5 \%$ of the interviewees have less than once a month the consumption of fruits and vegetables, and that $71.25 \%$ of them reported that consuming fruits and vegetables of the time.

The fruits that the interviewees reported consumed more frequently (four or more times a day) was orange and mandarin where women had a frequency of consumption of $26.25 \%$ and men of $17.5 \%$ (Table 4 ). For most of the patients interviewed, they had frequency of mango, papaya and banana consumption between two and six times a week of $48.75 \%$ of women and $40 \%$ men. The frequency of fruit salad consumption between two and six times a week observed that $33.75 \%$ of women and $36.25 \%$ of men consume.

\begin{tabular}{|l|c|c|c|c|}
\hline Frequência & $\begin{array}{c}\text { Todos } \\
(\mathbf{n = 8 0} \\
\mathbf{n}(\%)\end{array}$ & $\begin{array}{c}\text { Homens } \\
\mathbf{n}(\%)\end{array}$ & $\begin{array}{c}\text { Mulheres } \\
\mathbf{n}(\%)\end{array}$ & $\mathbf{P}$ \\
\hline $\begin{array}{l}\text { Weekly } \\
\text { Never }\end{array}$ & $3(3,8)$ & $2(2,5)$ & $1(1,3)$ & 0,06 \\
\hline 1 Time per week & $34(42,5)$ & $15(18,7)$ & $19(23,8)$ & \\
\hline 2-3 Times a week & $17(21,3)$ & $7(8,8)$ & $10(12,5)$ & \\
\hline 4-5 Times a week & $15(18,7)$ & $8(10,0)$ & $7(8,7)$ & \\
\hline + 6 Timesa a week & $11(13,7)$ & $4(5,0)$ & $7(8,7)$ & \\
\hline Total & $80(100)$ & $36(45)$ & $44(55)$ & \\
\hline $\begin{array}{l}\text { Monthly } \\
\text { Never <1 Time } \\
\text { per month }\end{array}$ & $76(8,75)$ & $3(3,75)$ & $4(5,0)$ & 0,05 \\
\hline $\begin{array}{l}\text { 1-3 Times a } \\
\text { month }\end{array}$ & $27(33,75)$ & $9(11,25)$ & $18(22,5)$ & \\
\hline $\begin{array}{l}\text { Seasonality Dur- } \\
\text { ing the season }\end{array}$ & $57(71,25)$ & $24(30)$ & $(41,25)$ & 0,07 \\
\hline All year round & $23(28,75)$ & $9(11,25)$ & $14(17,5)$ & \\
\hline
\end{tabular}

Table 3: Frequency of weekly, monthly and seasonal consumption of fruits and vegetables.

\begin{tabular}{|l|c|c|c|c|c|c|}
\hline Alimentos & Sex & $\begin{array}{c}\text { Never or less than 1 } \\
\text { time/month n (\%) }\end{array}$ & $\begin{array}{c}\text { 1-4Times/month } \\
\mathbf{n ~ ( \% )}\end{array}$ & $\begin{array}{c}\mathbf{2 - 6} \text { Times/week } \\
\mathbf{n}(\%)\end{array}$ & $\begin{array}{c}\mathbf{1 - 3} \text { Times/day } \\
\mathbf{n}(\%)\end{array}$ & $\begin{array}{c}\text { 4 or more times/day } \\
\mathbf{n}(\%)\end{array}$ \\
\hline Laranja, Tangerina & $\mathrm{F}$ & $7(8,75)$ & $9(11,25)$ & $34(42,5)$ & $14(17,5)$ & $21(26,25)$ \\
& $\mathrm{M}$ & $5(6,25)$ & $17(21,25)$ & $23(28,7)$ & $9(11,25)$ & $14(17,5)$ \\
\hline Apple, pear & $\mathrm{F}$ & $13(16,25)$ & $28(35)$ & $25(31,25)$ & $13(16,25)$ & $2(2,5)$ \\
& $\mathrm{M}$ & $9(11,25)$ & $13(16,25)$ & $17(21,25)$ & $11(13,7)$ & $6(7,5)$ \\
\hline Watermelon, & $\mathrm{F}$ & $32(40)$ & $34(42,5)$ & $27(33,75)$ & $15(18,7)$ & $0(0,0)$ \\
Melona & $\mathrm{M}$ & $27(33,75)$ & $10(12,5)$ & $19(23,75)$ & $6(7,5)$ & $0(0,0)$ \\
\hline Grapes & $\mathrm{F}$ & $28(35)$ & $26(32,5)$ & $34(42,5)$ & $8(10)$ & $0(0,0)$ \\
\hline & $\mathrm{M}$ & $14(17,5)$ & $14(17,5)$ & $24(30)$ & $13(16,2)$ & $0(0,0)$ \\
\hline Passion fruit & $\mathrm{F}$ & $17(21,25)$ & $19(23,75)$ & $26(32,5)$ & $21(26,2)$ & $0(0,0)$ \\
& $\mathrm{M}$ & $21(26,25)$ & $24(30)$ & $20(25)$ & $11(13,7)$ & $0(0,0)$ \\
\hline Avocado & $\mathrm{F}$ & $27(33,75)$ & $29(36,25)$ & $31(38,75)$ & $17(21,25)$ & $8(10)$ \\
& $\mathrm{M}$ & $24(30)$ & $32(40)$ & $33(41,25)$ & $10(12,5)$ & $0(0,0)$ \\
\hline
\end{tabular}




\begin{tabular}{|c|c|c|c|c|c|c|}
\hline Ata & $\begin{array}{l}\mathrm{F} \\
\mathrm{M}\end{array}$ & $\begin{array}{c}16(20) \\
13(16,25)\end{array}$ & $\begin{array}{c}21(26,25) \\
16(20)\end{array}$ & $\begin{array}{r}23(28,75) \\
18(22,5)\end{array}$ & $\begin{array}{c}5(6,25) \\
9(11,25)\end{array}$ & $\begin{array}{l}6(7,5) \\
8(10)\end{array}$ \\
\hline Natural fruit sumo & $\begin{array}{l}\mathrm{F} \\
\mathrm{M} \\
\end{array}$ & $\begin{array}{l}10(12,5) \\
11(13,75)\end{array}$ & $\begin{array}{l}13(16,25) \\
15(18,75)\end{array}$ & $\begin{array}{c}17(21,25) \\
14(17,5)\end{array}$ & $\begin{array}{c}13(16,5) \\
7(8,75)\end{array}$ & $\begin{array}{l}0(0,0) \\
0(0,0)\end{array}$ \\
\hline Fruit salt & $\begin{array}{l}\mathrm{F} \\
\mathrm{M}\end{array}$ & $\begin{array}{l}26(32,5) \\
22(27,5)\end{array}$ & $\begin{array}{c}26(32,5) \\
23(28,75)\end{array}$ & $\begin{array}{l}27(33,75) \\
29(36,25)\end{array}$ & $\begin{array}{c}16(2) \\
18(22)\end{array}$ & $\begin{array}{l}0(0,0) \\
0(0,0)\end{array}$ \\
\hline Canned fruit & $\begin{array}{l}\mathrm{F} \\
\mathrm{M}\end{array}$ & $\begin{array}{c}15(18,75) \\
6(7,5)\end{array}$ & $\begin{array}{l}16(20) \\
8(10)\end{array}$ & $\begin{array}{l}19(23,75) \\
13(16,25)\end{array}$ & $\begin{array}{c}0(0,0) \\
3(3,75)\end{array}$ & $\begin{array}{l}0(0,0) \\
0(0,0)\end{array}$ \\
\hline $\begin{array}{l}\text { Mango, Papaya, } \\
\text { Banana }\end{array}$ & $\begin{array}{l}\mathrm{F} \\
\mathrm{M}\end{array}$ & $\begin{array}{c}4(5) \\
9(11,25)\end{array}$ & $\begin{array}{c}37(46,25) \\
30(37,5)\end{array}$ & $\begin{array}{c}39(48,75) \\
32(40)\end{array}$ & $\begin{array}{l}23(28) \\
19(23)\end{array}$ & $\begin{array}{l}13(16,25) \\
17(21,25)\end{array}$ \\
\hline Litxi, Pineapple & $\begin{array}{l}\mathrm{F} \\
\mathrm{M}\end{array}$ & $\begin{array}{c}12(15) \\
18(22,5)\end{array}$ & $\begin{array}{l}19(23,75) \\
27(33,75)\end{array}$ & $\begin{array}{l}17(21,25) \\
29(36,25)\end{array}$ & $\begin{array}{l}15(18) \\
0(0,0)\end{array}$ & $\begin{array}{l}0(0,0) \\
0(0,0)\end{array}$ \\
\hline
\end{tabular}

Table 4: Frequency of fruit consumption according to gender.

In the frequency assessment of melance and melon consumption, it was observed that less than once a month or even never by $40 \%$ of women and $33.75 \%$ of men are consumed.

In the evaluation of the frequency of vegetable consumption, it was found that $21.25 \%$ of women and $16.25 \%$ men reported consuming tomatoes and onions four or more times a day, and regarding the consumption of cooked vegetables (cassava leaves, pumpkin, beans, cabbage) it was observed that $45 \%$ of women and $28.75 \%$ men reported consuming between two and six times a week (Table 5). Of the patients interviewed, it was observed that $36.25 \%$ of men and $21.25 \%$ of women consumed less than once a month or even never beet.

\begin{tabular}{|c|c|c|c|c|c|c|}
\hline Food & Sex & $\begin{array}{l}\text { Never or less than } 1 \\
\text { time/month } \mathbf{n}(\%)\end{array}$ & $\begin{array}{c}\text { 1-4Times /month } \\
\text { n (\%) }\end{array}$ & $\begin{array}{c}\text { 2-6 Times/ } \\
\text { week } \\
\text { n (\%) }\end{array}$ & $\begin{array}{c}\text { 1-3 Times/ } \\
\text { day } \\
\text { n (\%) }\end{array}$ & $\begin{array}{c}4 \text { or more } \\
\text { times/day } \\
n(\%)\end{array}$ \\
\hline $\begin{array}{l}\text { Cooked (cassava leaves, pump- } \\
\text { kin, beans, cabbage) }\end{array}$ & $\begin{array}{l}\mathrm{F} \\
\mathrm{M}\end{array}$ & $\begin{array}{l}8(10) \\
3(3,75)\end{array}$ & $\begin{array}{l}9(11,25) \\
17(21,25)\end{array}$ & $\begin{array}{l}36(45) \\
23(28)\end{array}$ & $\begin{array}{l}14(17,5) \\
9(11,25)\end{array}$ & $\begin{array}{l}0(0,0) \\
0(0,0)\end{array}$ \\
\hline $\begin{array}{l}\text { Raw vegetables (carrot, cucum- } \\
\text { ber, cabbage, lettuce) }\end{array}$ & $\begin{array}{l}\mathrm{F} \\
\mathrm{M}\end{array}$ & $\begin{array}{l}10(12,5) \\
11(13,75)\end{array}$ & $\begin{array}{c}28(35) \\
13(16,25)\end{array}$ & $\begin{array}{l}25(31,25) \\
17(21,25)\end{array}$ & $\begin{array}{l}13(16,25) \\
11(13,75)\end{array}$ & $\begin{array}{l}0(0,0) \\
0(0,0)\end{array}$ \\
\hline Tomato, Onin & $\begin{array}{l}\mathrm{F} \\
\mathrm{M}\end{array}$ & $\begin{array}{l}5(6,25) \\
9(11,25)\end{array}$ & $\begin{array}{l}34(42,5) \\
10(12,5)\end{array}$ & $\begin{array}{l}33(41,25) \\
19(23,75)\end{array}$ & $\begin{array}{c}21(26,25) \\
32(40)\end{array}$ & $\begin{array}{l}17(21,25) \\
13(16,25)\end{array}$ \\
\hline Pimento & $\mathrm{F}$ & $21(26,25)$ & $26(32,5)$ & $34(42,5)$ & $8(10)$ & $0(0,0)$ \\
\hline & M & $29(36,25)$ & $14(17,5)$ & $24(30)$ & $13(16,25)$ & $0(0,0)$ \\
\hline Beet & $\begin{array}{l}\mathrm{F} \\
\mathrm{M}\end{array}$ & $\begin{array}{c}17(21,25) \\
7(8,75)\end{array}$ & $\begin{array}{c}19(23,75) \\
24(30)\end{array}$ & $\begin{array}{l}26(32,5) \\
20(25)\end{array}$ & $\begin{array}{c}21(26,25) 11 \\
(13,75)\end{array}$ & $\begin{array}{l}0(0,0) \\
0(0,0)\end{array}$ \\
\hline Moringa & $\begin{array}{l}\mathrm{F} \\
\mathrm{M}\end{array}$ & $\begin{array}{l}5(6,25) \\
2(2,5)\end{array}$ & $\begin{array}{l}13(16,25) \\
11(13,75)\end{array}$ & $\begin{array}{l}0(0,0) \\
0(0,0)\end{array}$ & $\begin{array}{l}10(12,5) \\
7(8,75)\end{array}$ & $\begin{array}{l}0(0,0) \\
0(0,0)\end{array}$ \\
\hline Eggplant & $\begin{array}{l}\mathrm{F} \\
\mathrm{M}\end{array}$ & $\begin{array}{c}11(13,75) \\
8(10)\end{array}$ & $\begin{array}{c}21(26,25) \\
16(20)\end{array}$ & $\begin{array}{l}23(28,75) \\
18(22,5)\end{array}$ & $\begin{array}{l}5(6,25) \\
9(11,25)\end{array}$ & $\begin{array}{l}0(0,0) \\
0(0,0)\end{array}$ \\
\hline
\end{tabular}

Table 5: Frequency of vegetable consumption. 


\section{Discussion}

The results of the present study indicate that in the sample evaluated the frequency of fruit and vegetable consumption in most participants, $42.5 \%$ for fruits and $23.7 \%$ for vegetables was less than once a day. Regarding the frequency of consumption equal to two/three or five times a day, $18.8 \%$ of men and $21.2 \%$ women had this frequency of consumption, and for plants $25 \%$ of women and $27.5 \%$ men.

The fruits that observed the highest frequency of consumption were mango, papaya and bananas that $48.75 \%$ of women and $40 \%$ of men had a consumption between two and six times a week, and fruit salad had a frequency of consumption of $33.75 \%$ in women and $36.25 \%$ of men. As for vegetables, it was observed that $45 \%$ of women and $28.75 \%$ of men reported consuming cooked vegetables (cassava leaves, pumpkin, beans, cabbage) between two and six times a week.

In the frequency assessment of watermelon and melon consumption, it was observed that the interviewees consumed less than once a month or even never in $40 \%$ of women and $33.75 \%$ men, as well as it was observed that $36.25 \%$ of men and $21.25 \%$ of women consumed less than once per time month or even never beetroot.

In a study on food consumption with a sample of 41 individuals, $75.6 \%$ were women, they observed that less than half $40.0 \%$ of the participants consumed fruits and vegetables daily [12]. Although no statistically significant differences in the frequency of fruit and vegetable consumption between the sexes have been found, other studies have shown a more appropriate dietary pattern among women, with a tendency to achieve recommendations for the consumption of fruits and vegetables [12].

In Mozambique, there are no studies that have evaluated the consumption of the population, specifically regarding the frequency of consumption of fruits and vegetables, with only information on food consumption at household level, such as present in the Food and Nutrition Safety Monitoring Report [13]. The information contained in the SETSAN Report has allowed consumption inferences, although not individualized. On the other hand, combining these data with those obtained in smaller consumption studies in different locations, it is verified that the consumption of fruits and vegetables is insufficient $[13,14]$. However, in a study on eating habits with 126 individuals of whom 57.9\% were women, they had the higher frequency of consumption because $47.5 \%$ of women and $38.3 \%$ of men consumed four times a day of fruits and vegetables [15].

The low frequency of fruit and vegetable consumption becomes worrisome, as these foods are rich in vitamins, minerals and food fibres and should be part of feeding individuals of all age groups because they contribute to the protection of reduction of the risk of occurrence of various chronic diseases [10]. The educational level is an aspect that could justify the low consumption of fruits and vegetables, involved with the attitude of consuming these foods or not [14].

Family income is related to food consumption since it determines food availability and accessibility, this factor may have contributed to the results of the low frequency of fruit and vegetable consumption, as well as the period in which data collection may have exerted some influence on the results due to the seasonality of these products $[14,15]$.

The application of the FFQ brought some limitations, particularly resulting from the restrictions imposed by a fixed list of food, dependence on memory on consumption influencing the memory of the past, requiring much cooperation from respondents and perception of the average portions of food. In order to minimize these potential errors of the questionnaire was based on a personal interview which allowed better assistance to the participant, clarifying doubts at the time of the interview. At the time of the study, i would be interested in comparing the frequency of fruit and vegetable consumption among HIV patients in outpatient clinics and hospitalized, it was not possible to perform due to the scarce period of data collection and in this period observing few hospitalized patients.

\section{Conclusion}

The studied group showed inadequate frequency consumption of fruits and vegetables, however, although the results did not present differences statistically significant consumption among gender. In view of this, there is a need to encourage the consumption of these foods, in addition to the adoption of healthy eating habits and should not be seen as an individual effort, as it also depends 
on government initiatives that potentially in and drive changes in multiple behaviors through health promotion and contribute to the improvement of their nutritional status and quality of life.

\section{Bibliography}

1. Mahan K and Scott-Stump S. "Food, Nutrition and Dietotherapy”. 11th ed. São Paulo: Roca (2005): 337-43.

2. World Health Organization (WHO). Diet, Nutrition and the Prevention of Chronic Diseases. Geneva (2010).

3. Monaso. HIV situation analysis and AIDS and Access to ART in Mozambique, Report produced for the 1st Conference of Civil Society on HIV and AIDS in Mozambique (2008): 13-17.

4. Republic of Mozambique. National Strategic Plan for HIV response and AIDS 2010-2014 (2009): 9-14.

5. Antunes M., et al. "Determinants of nutritional status in patients with AIDS". (1994): 209-220.

6. Giraldo R. "Nutritional therapy for the treatment and prevention of SIDA" (2002).

7. Chandra R. Nutrition and the immune system: An Introduction Clinic Nutrition (1997): 460-63.

8. Food and Nutrition Technical Assistance Project (FANTA) HIV/AIDS: A Guide for Nutritional Care and Support. $2^{\text {nd }}$ Edition. Washington D.C.: Academy for Educational Development (2004): 23-37.

9. Duran A., et al. "Diet quality of persons living with HIV/AIDS on highly active antiretroviral therapy". Journal of Human $\mathrm{Nu}$ trition and Dietetics 21 (2008): 346-350.

10. Janaina Lavalli A. Quality of diet of adults living with HIV/ AIDS and its associated factors. Dissertation (Master's degree in Nutrition) - Faculty of Health Public of the University of São Paulo (2009).

11. Lopes C., et al. "Food consumption in Porto". Faculty of Medicine, University of Port (2006).

12. Coca A and Daniela B. Food consumption and its influence on the control of hypertension of adults and the elderly of both sexes in a basic health unit in Dourados - MS (2010).
13. Technical Secretariat for Food and Nutrition Safety (SETSAN). Report of the Monitoring of Food and Nutrition Security in Mozambique (2008).

14. Technical Secretariat for Food and Nutrition Safety (SETSAN), Strategy and Action Plan for Food and Nutrition Security 2008-2015 (2007).

15. Geiger J and Couto S. "Early morning S: Frequency of Consumption of Fruits, Vegetables and Vegetables in Pellet Adolescents" (2010).

Volume 3 Issue 12 December 2019

(c) All rights are reserved by Sousa Gastao. 